\title{
"Ceria”
}

Jurnal Program Studi Pendidikan Anak Usia Dini

ISSN 2301-9905

Volume 10, No 1, Juli 2021

Fakultas Keguruan dan IImu Pendidikan- Universitas Muhammadiyah Tangerang

\section{PENGEMBANGAN MEDIA MAKET TATA SURYA PADA ANAK USIA}

DINI

\author{
${ }^{1}$ Titi Rachmi, ${ }^{2}$ Nuraeni \\ ${ }^{1,2}$ Program Studi Pendidikan Guru Pendidikan Anak Usia Dini, Fakultas Keguruan Dan Ilmu \\ Pendidikan, Universitas Muhammadiyah Tangerang \\ e-mail: ${ }^{1}$ Titirachmi@gmail.com, ${ }^{2}$ nuraeni.zumi@gmail.com
}

\begin{abstract}
Abstrak
Penelitian ini bertujuan merancang, mendesain, membuat dan menguji kelayakan sebuah produk yaitu berupa media pembelajaran yang layak digunakan untuk pembelajaran materi Tata surya. Media yang dihasilkan dalam penelitian berupa "Media Maket Tata Surya Pada Anak Usia Dini". Jenis Penelitian yang digunakan dalam penelitian ini adalah Research \& Development $(\mathrm{RnD})$ dengan model pendekatan ADDIE (Analysis, Design, Development, Implementation, and Evaluation) penelitian dilakukan sesuai prosedur pengembangan secara sistematis, tahap pertama pendahuluan pengumpulan data/informasi, tahap kedua perencanaan dan pengembangan pembuatan produk dengan mengrealisasikan konsep dari produk yang akan dibuat dan didesain, kemudian pengujian penilaian validasi ahli dan penilaian tanggapan pengguna media, tahap ketiga adalah revisi dan evaluasi yaitu perbaikan dan mengevaluasi dari setiap langkah kegiatan uji coba lapangan melalui uji coba lapangan awal dan uji coba lapangan produk utama, tahap keempat implementasi dan desiminasi yaitu sosialisasi dan penyebaran. Hasil penelitian menunjukan bahwa Media Maket Tata Surya memperoleh penilaian dari para ahli diantaranya ahli materi memperoleh kriteria"Layak"dengan persentase sebesar 76,9\%, ahli media memperoleh kriteria "Sangat Layak" dengan persentase sebesar 83,5\% dan hasil penilaian tanggapan pengguna media memperoleh kriteria"Sangat Layak" dengan persentase sebesar 95,3\% sedangkan hasil uji coba lapangan awal dan uji coba produk utama melalui catatan lapangan menunjukan bahwa media ini memudahkan anak dalam mengenal nama dan urutan Planet dalam Tata Surya.
\end{abstract}

Kata Kunci:media, maket tata surya, anakusiadini 


\section{Pengantar}

Media sebagai sumber belajar yang efektif menjadi hal yang menentukan dalam proses pendidikan untuk mencapai tujuan pendidikan. Media adalah bagian yang tidak terpisahkan dari proses belajar mengajar demi tercapainya tujuan pendidikan pada umumnya dan tujuan pembelajaran disekolah pada khususnya. Penguasaan materi dan aktivitas belajar siswa sangat mungkin diwujudkan apabila didukung dengan penggunaan media ketika proses belajar berlangsung. Hal ini dipertegas oleh Sudjana dan Rivai bahwa pembelajaran akan lebih efektif jika materi yang disampaikan oleh seorang guru kepada siswa di visualisasikan secara nyata menyerupai kondisi maupun bentuk yang sebenarnya (Aziz \& Prasetya, 2018). Penggunaan media dalam bentuk visual konkret yang dapat siswa lihat dengan langsung, maka akan sangat membantu guru dalam menyampaikan materi.

Penggunaan media sebagai sumber belajar secara tepat merupakan hal yang penting dalam membantu proses berpikir anak, karena media mempunyai berbagai kelebihan antara lain membuat konsep abstrak menjadi sesuatu konsep yang nyata, sederhana, sistematis dan jelas. Menurut Mc Luahan media adalah saluran karena hakikatnya media telah memperluas atau memperpanjang kemampuan manusia untuk merasakan, mendengar dan melihat dalam batasbatas jarak, ruang dan waktu tertentu dengan bantuan itu batas-batas menjadi tidak ada, terlebih untuk Anak Usia Dini (AUD) yang kemampuan berfikirnya masih bersifat konkret sangat memerlukan media sebagai perantara untuk mengkronkitkan sebuah konsep sehingga mudah dipahami (Hilmi, et al., 2017) .

Proses kegiatan belajar anak usia dini yang terpenting adalah menghadirkan media sebagai saluran atau wadah yang berisi informasi materi pembelajaran. Maka demi tercapainya tujuan pembelajaran, para pendidik menyediakan dan menyiapkan media sebagai perantara yang bisa anak rasakan, yang bisa anak lihat, yang bisa anak amati melalui panca indera nya tanpa ada batasan jarak, ruang dan waktu. Proses kegiatan belajar mengajar haruslah 
menarik, efektif dan efisisen. Maka di perlukan alat bantu atau media belajar sebagai alat pendukung dalam proses belajar mengajar. Media harus dapat membuat anak belajar secara aktif dan menyenangkan. Tentunya media harus berorientasi pada tahap perkembangan anak. Adanya media pembelajaran ini akan mempermudah penyampaian materi tentang tata surya yang termasuk ke dalam kurikulum 2013 yang termuat dalam tema Alam Semesta yang mengandung Kompetensi Dasar (KD) sesuai pengelompokan Kompetensi Inti (KI) yaitu sikap spiritual, sikap sosial, pengetahuan dan keterampilan.

Materi mengenai tata surya di lembaga pendidikan anak usia dini masih banyak diajarkan dengan cara monoton dan terbatas yakni menggunakan media buku LKS maupun gambar. Hal ini membuat suasana kegiatan belajar mengajar menjadi membosankan bagi anak karena anak menjadi pembelajar pasif dan pembelajaran pun menjadi berpusat pada guru (teacher centered). Hasil Prapenelitian di TKQ Daarul Athfaal kecamatan Legok Kabupaten Tangerang kegiatan proses belajar mengajar saat materi Tata Surya pada tema Alam Semesta menggunakan media yang berupa gambar.

\section{Metode}

Penelitian pengembangan Media Maket Tata Surya Pada Anak Usia Dini mengacu pada jenis penelitian pengembangan (Research and Development). Penelitian dan pengembangan (R\&D) adalah metode penelitian yang digunakan untuk menghasilkan rancangan produk baru, menguji keefektifan produk yang telah ada, serta mengembangkan dan menciptakan produk baru. Apabila produk baru telah teruji, maka produk tersebut bila digunakan dalam pekerjaan akan lebih mudah, lebih cepat, kuantitas dan kualitas produk hasil kerja akan meningkat (Sugiyono, 2019: 26). Adaptasi dari prosedur untuk penelitian ini memiliki 10 langkah, yakni (1) pengumpulan data (2) perencanaan penelitian dan pengembangan (3) tahap pengembangan (4) uji coba lapangan awal (5) revisi hasil uji coba (6) uji coba lapangan produk utama (7) revisi produk (8) uji coba lapangan skala luas (9) revisi produk final (10) desiminasi dan implementasi. 


\section{Hasil dan Pembahasan}

Penyajian data uji coba kuantitatif yaitu peneliti menjelaskan hasil prosedur telaah dan hasil validasi panel secara kuantitatif. Peneliti menyajikan hasil uji validasi atau penilaian oleh ahli materi, ahli media dan tanggapan pengguna media dalam bentuk tabel. Selanjutnya peneliti menyajikan hasil validasi kontruk/isi yang dilakukan dengan telaah pakar/panel yang menjelaskan uji validitas dan reabilitas menggunakan Uji Panelis Aiken untuk mengukur taraf kepercayaan setiap butir instrumen.

Tabel 1

Hasil Uji Validasi Ahli Materi

\begin{tabular}{|c|c|c|c|c|c|c|c|c|c|c|c|c|}
\hline \multirow{3}{*}{ No } & \multirow{3}{*}{ Panelis } & \multicolumn{7}{|c|}{ Aspek Kualitas Isi } & \multicolumn{4}{|c|}{$\begin{array}{l}\text { Aspek Kualitas } \\
\text { Instruksional }\end{array}$} \\
\hline & & \multicolumn{11}{|c|}{ Butir Pernyataan } \\
\hline & & 1 & 2 & 3 & 4 & 5 & 6 & 7 & 8 & 9 & 10 & 11 \\
\hline 1 & P01 & 3 & 3 & 4 & 3 & 3 & 3 & 4 & 4 & 4 & 4 & 4 \\
\hline 2 & P02 & 4 & 4 & 3 & 3 & 4 & 4 & 3 & 4 & 4 & 4 & 4 \\
\hline 3 & P03 & 5 & 4 & 4 & 3 & 4 & 3 & 3 & 4 & 4 & 4 & 4 \\
\hline 4 & P04 & 4 & 4 & 4 & 4 & 4 & 4 & 4 & 3 & 3 & 4 & 5 \\
\hline 5 & P05 & 4 & 4 & 4 & 3 & 3 & 3 & 3 & 3 & 4 & 4 & 4 \\
\hline 6 & P06 & 5 & 4 & 5 & 4 & 4 & 5 & 4 & 5 & 4 & 4 & 4 \\
\hline \multicolumn{2}{|c|}{$\begin{array}{c}\text { Skor } \\
\text { Maksimal }\end{array}$} & 30 & 30 & 30 & 30 & 30 & 30 & 30 & 30 & 30 & 30 & 30 \\
\hline \multicolumn{2}{|c|}{$\begin{array}{l}\text { Skor yang } \\
\text { Diperoleh }\end{array}$} & 25 & 23 & 24 & 20 & 22 & 22 & 21 & 23 & 23 & 24 & 25 \\
\hline \multicolumn{2}{|c|}{ Persentase } & 83,3 & 76,6 & 80,0 & 66,6 & 73,3 & 73,3 & 70,0 & 76,6 & 76,6 & 80,0 & 83,3 \\
\hline \multicolumn{2}{|c|}{$\begin{array}{l}\text { Persentase } \\
\text { Aspek }\end{array}$} & \multicolumn{7}{|c|}{74,7} & \multicolumn{4}{|c|}{79,1} \\
\hline \multicolumn{2}{|c|}{ Rata-rata } & \multicolumn{11}{|c|}{76,9} \\
\hline \multicolumn{2}{|c|}{ Kriteria } & \multicolumn{11}{|c|}{ Layak } \\
\hline
\end{tabular}


Berdasarkan tabel di atas dihitung secara kuantitatif dengan rumus sebelumnya yaitu skor yang diperoleh dibagi skor maksimal dikalikan seratus persen, kemudian hasilnya dideskripsikan secara kualitatif dengan kategori yang ditetapkan sebelumnya, yaitu 0\%-20\% berarti Sangat Tidak Layak, 21\%- 40\% berarti Tidak Layak, 41\%-60\% berarti Cukup Layak, 61\%80\% berarti Layak, 81\%-100\% berarti Sangat Layak (Ridwan, 2013: 15). Hasil uji validasi dari ahli materi hasil persentase kelayakannya ratarata76,9\% dan dikategorikan dengan kriteria "Layak". Maka hasil validasi Media Maket Tata Surya menurut para ahli materi adalah layak untuk diuji cobakan ketahap selanjutnya dengan beberapa saran dan revisi yang harus diperbaiki.

Tabel 3

Hasil Uji Validasi Ahli Media

\begin{tabular}{|c|c|c|c|c|c|c|c|c|c|}
\hline \multirow{3}{*}{ No } & \multirow{3}{*}{ Panelis } & \multicolumn{8}{|c|}{ Aspek Fisik, Warna dan Pemakaian } \\
\hline & & \multicolumn{8}{|c|}{ Butir Pernyataan } \\
\hline & & 1 & 2 & 3 & 4 & 5 & 6 & 7 & 8 \\
\hline 1 & P01 & 4 & 5 & 4 & 4 & 4 & 4 & 4 & 5 \\
\hline 2 & P02 & 4 & 5 & 4 & 3 & 3 & 4 & 3 & 5 \\
\hline 3 & P03 & 4 & 5 & 5 & 4 & 3 & 4 & 4 & 5 \\
\hline 4 & P04 & 4 & 5 & 4 & 4 & 4 & 4 & 3 & 4 \\
\hline 5 & P05 & 4 & 5 & 5 & 4 & 4 & 4 & 5 & 5 \\
\hline \multicolumn{2}{|c|}{$\begin{array}{l}\text { Skor } \\
\text { Maksimal }\end{array}$} & 25 & 25 & 25 & 25 & 25 & 25 & 25 & 25 \\
\hline \multicolumn{2}{|c|}{$\begin{array}{l}\text { Skor yang } \\
\text { Diperoleh }\end{array}$} & 20 & 25 & 22 & 19 & 18 & 20 & 19 & 24 \\
\hline \multicolumn{2}{|c|}{ Persentase } & 80 & 100 & 88 & 76 & 72 & 80 & 76 & 96 \\
\hline \multicolumn{2}{|c|}{ Rata-rata } & \multicolumn{8}{|c|}{83,5} \\
\hline \multicolumn{2}{|c|}{ Kriteria } & \multicolumn{8}{|c|}{$\begin{array}{l}\text { Sangat } \\
\text { Layak }\end{array}$} \\
\hline
\end{tabular}

Berdasarkan tabel di atas dihitung secara kuantitatif dengan rumus 
sebelumnya yaitu skor yang diperoleh dibagi skor maksimal dikalikan seratus persen, kemudian hasilnya dideskripsikan secara kualitatif dengan kategori yang ditetapkan sebelumnya, yaitu 0\%-20\% berarti Sangat Tidak Layak, 21\%- 40\% berarti Tidak Layak, 41\%-60\% berarti Cukup Layak, 61\%80\% berarti Layak, 81\%-100\% berarti Sangat Layak (Ridwan, 2013: 15). Hasil uji validasi dari ahli media hasil persentase kelayakannya rata-rata 83,5\% dan dikategorikan dengan kriteria "Sangat Layak". Maka hasil validasi Media Maket Tata Surya menurut para ahli media adalah Sangat Layak untuk diuji cobakan ketahap selanjutnya dengan beberapa saran dan revisi yang harus diperbaiki.

Langkah selanjutnya ialah uji coba dilapangan, Pelaksanan uji coba lapangan awal dilakukan pada 15 anak kelompok B dengan penyajian data dalam bentuk deskriptif kualitatif melalui catatan lapangan yang terdapat dalam lampiran. Catatan lapangan berisi hasil uji coba penggunaan media oleh peserta didik dari 3 Taman Kanak-Kanak se- Kecamatan Legok dengan berjumlah 5 anak pada tiap-tiap TK.

Pelaksanan uji coba lapangan produk utama berdasarkan hasil data uji coba lapangan awal yang dilakukan pada 15 anak kelompok B, maka dilakukan tahap selanjutnya yaitu uji coba lapangan produk utama yang dilakukan 25 anak dalam kelompok besar dalam 1 Taman Kanak-Kanak. Penyajian data dalam bentuk deskriptif kualitatif melalui catatan lapangan yang terdapat dalam lampiran. Catatan lapangan berisi hasil uji coba penggunaan media oleh 25 peserta didik kelompok B dengan rentang usia 5-6 tahun. Peneliti mencatat setiap kegiatan pada saat uji coba praktek dalam bentuk catatan lapangan yang terdapat dalam lampiran.

Perbaikan mengenai perubahan tersebut dilakukan dengan sedemikian rupa supaya media dapat diuji cobakan dilapangan. Berikut ini tabel yang menggambarkan perbaikan pada media Maket Tata Surya yang sebelum diperbaiki dan sesudah diperbaiki: 
Tabel 4

Hasil Revisi Berdasarkan Para Ahli

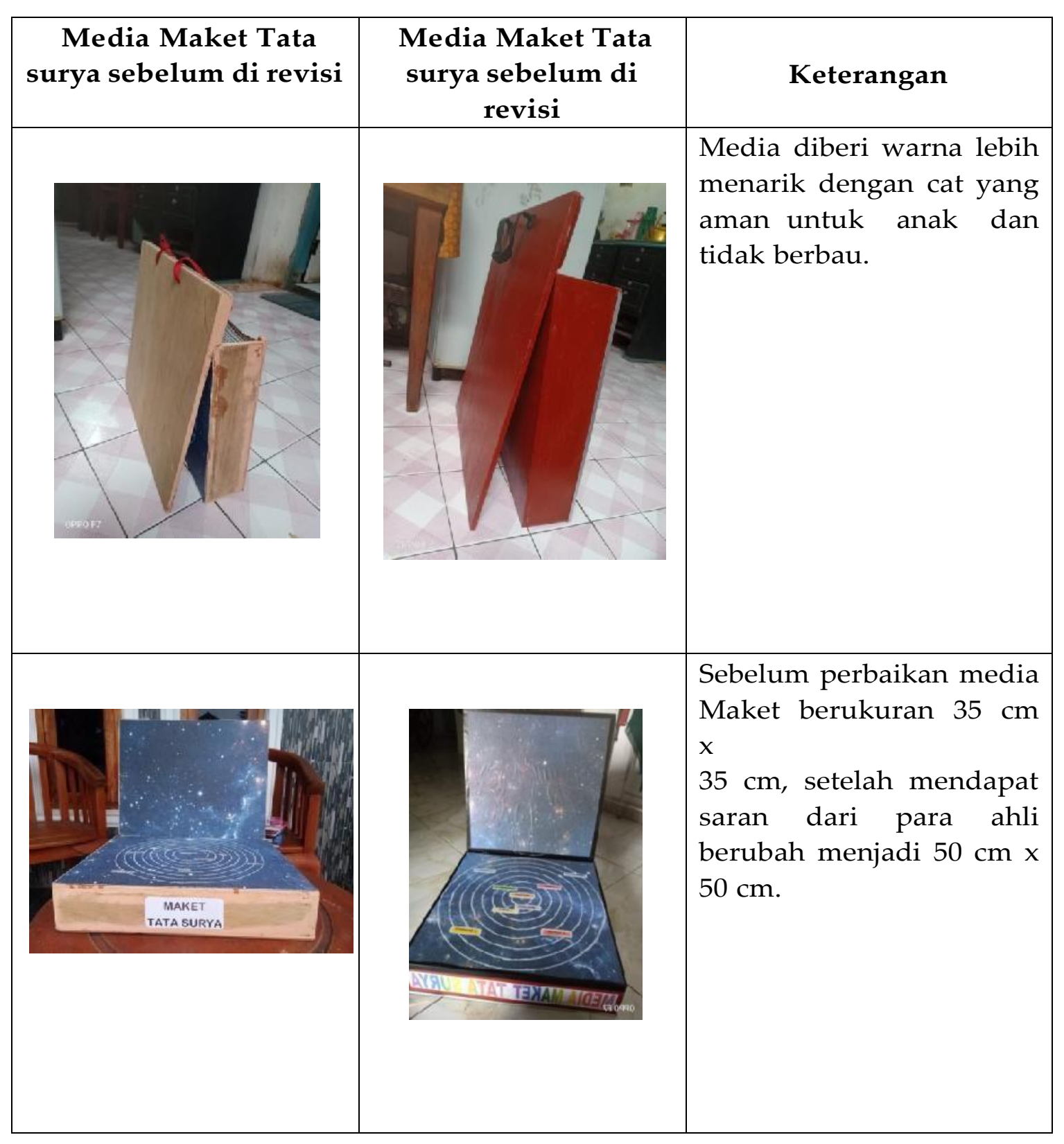



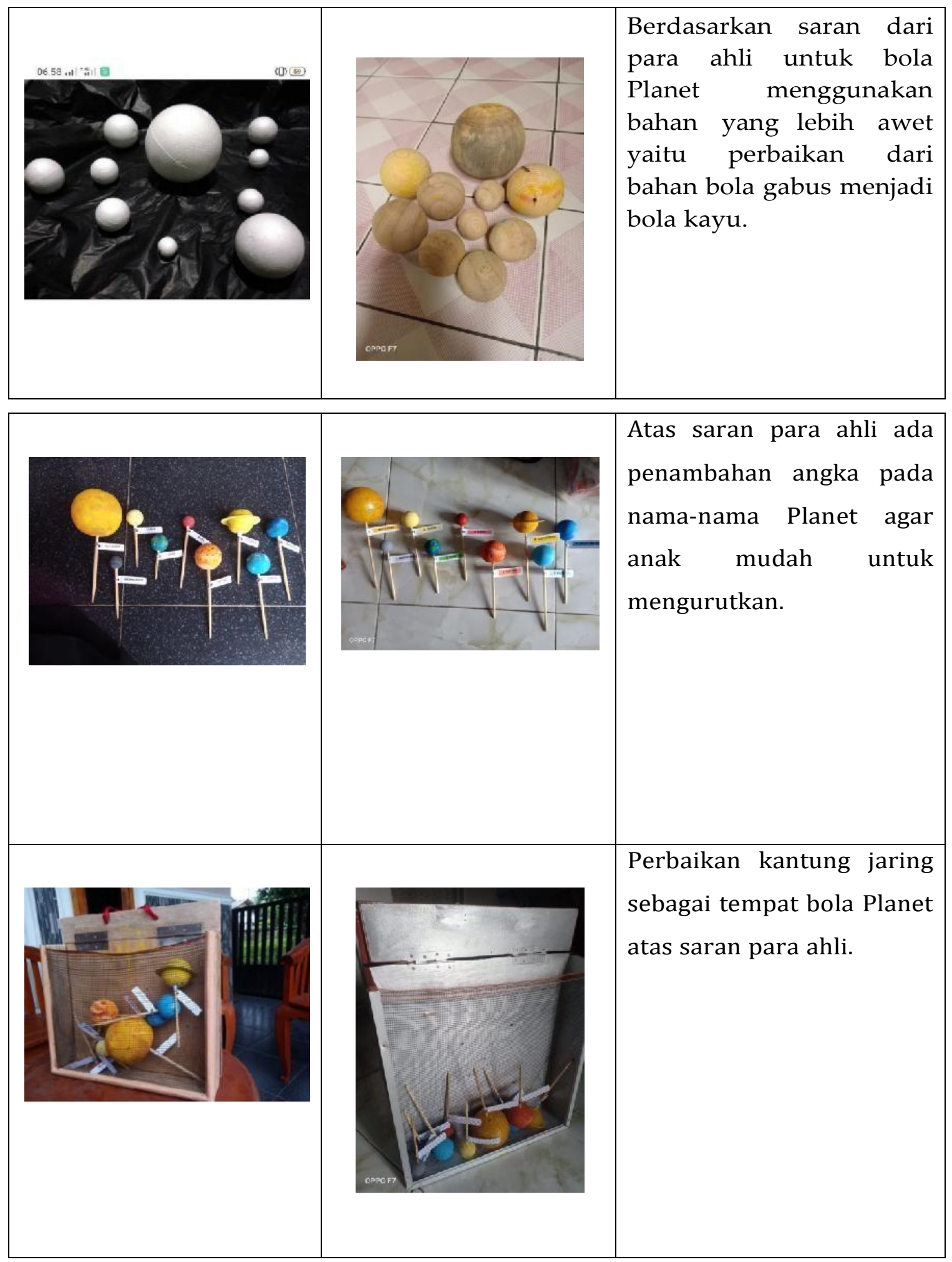


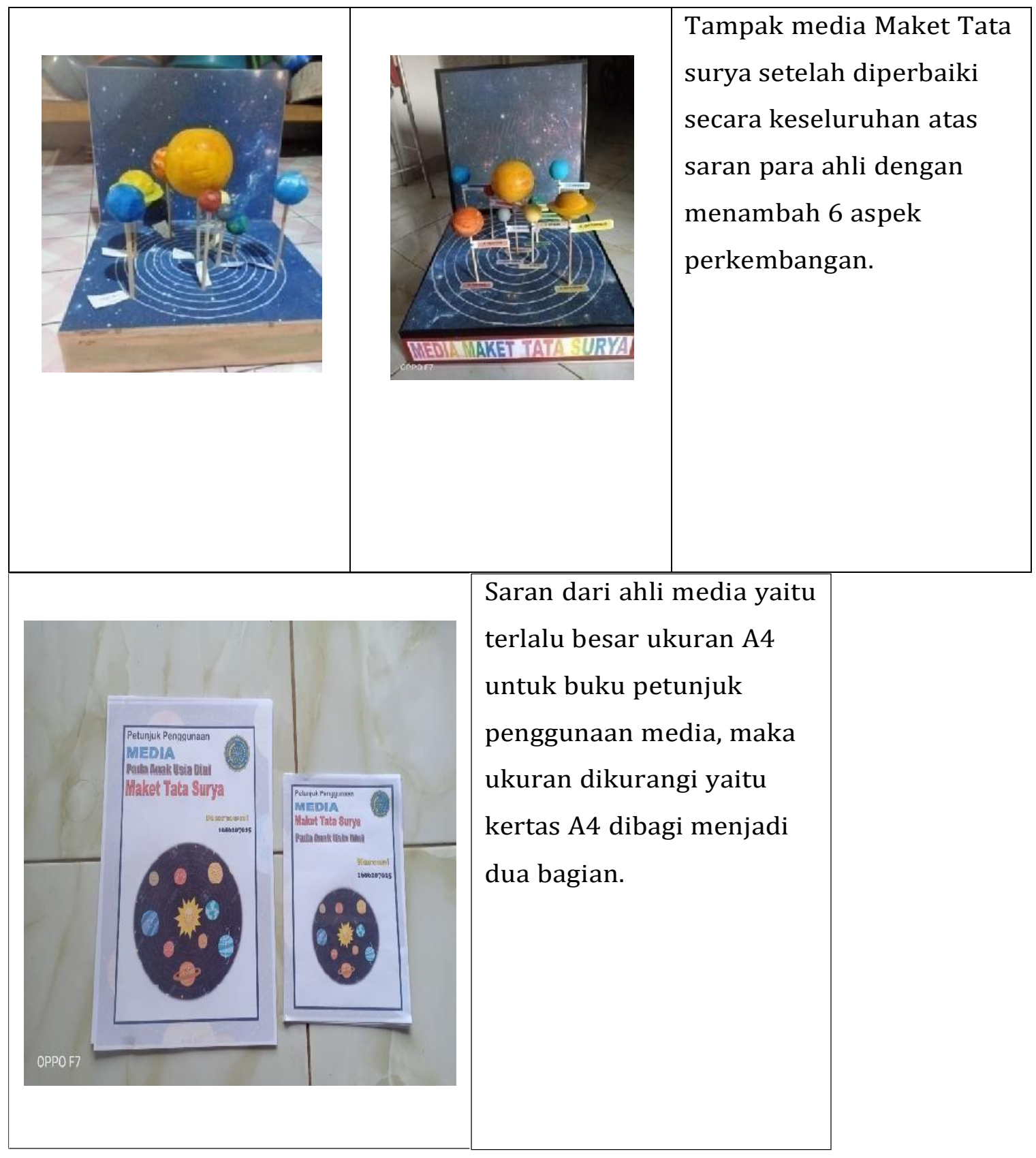

Menurut para ahli media dan ahli materi Media Maket Tata Surya layak digunakan dengan revisi dari beberapa masukan dan saran contohnya ada beberapa yang harus diperbaiki yaitu ukuran buku petunjuk media, ukuran media Maket Tata Surya, gradasi warna pada bola Planet, dan pewarnaan pada kemasan bagian luar media Maket Tata Surya. 


\section{Kesimpulan}

Penelitian dan pengembangan pada media Maket Tata surya dilakukan dengan sesuai prosedur pengembangan yang secara sistematis, prosedur tersebut diantaranya seperti: tahap pertama yaitu pendahuluan dengan pengumpulan data diantaranya menganalisis masalah dan analisis kebutuhan melalui pengumpulan data/informasi yang dilakukan dengan wawancara dan observasi sesuai dengan kebutuhan, mengkaji teori penelitian yang relevan yang berkaitan dengan produk tersebut, dan penelitian menganalisis produk yang telah ada untuk dikaji kelebihan dan kekurangan produk tersebut. Tahap kedua perancangan dan pengembangan produk yaitu dengan mengrealisasikan konsep dari produk yang akan dibuat dan didesain sedemikian rupa dengan perencanaan dan desain produk, selanjutnya pengembangan media Maket Tata Surya melalui produksi awal media Maket dengan spesifikasi kelebihan produk yang diharapkan dengan pengujian dan penilaian validasi ahli. Media Maket Tata Surya sudah dikatakan layak digunakan dalam proses pembelajaran pada anak usia dini. Kelayakan terhadap produk yang dibuat ini diperoleh dari hasil validasi oleh para ahli, tanggapan para pengguna. Validasi yang digunakan masing-masing dari ahli materi memperoleh kriteria"Layak"dengan persentase sebesar 76,9\%, dan validasi oleh ahli media mendapatkan kriteria "Sangat Layak" dengan memperoleh persentase sebesar $83,5 \%$. Sedangkan hasil penilaian tanggapan pengguna media Maket Tata Surya yang dilakukan Kepala Sekolah dan Guru memperoleh kriteria"Sangat Layak" dengan persentase sebesar 95,3\%.

Tahap ketiga revisi dan evaluasi yaitu tahap perbaikan dan mengevaluasi kegiatan dengan menilai apakah setiap langkah kegiatan dan produk yang telah dibuat sudah sesuai dengan spesifikasi atau belum, kegiatan yang dimaksud adalah 
pelaksanaan dan pemakaian produk melalui beberapa uji coba, uji coba lapangan awal yaitu pemakaian produk media yang dilakukan di 3 Taman Kanak-Kanak seKecamatan Legok pada 15 subjek, kemudian setelah mendapatkan hasil nya maka tahap berikutnya uji coba lapangan produk utama dengan menguji pada 25 subjek. Tahap keempat Tahap Implementasi dan Desiminasi yaitu tahap sosialisasi dan penyebaran.

Pengembangan media Maket Tata Surya tidak sampai kepada tahap ini, pengembangan media Maket Tata Surya hanya sampai pada tahap pendahuluan, perencanaan produk dan pengembangan, dan tahap revisi dan evaluasi. Akhir dari pengembangan sebuah produk yang dihasilkan yaitu berupa Media Maket Tata surya pada anak usia dini yang berbentuk media pembelajaran berisi tema Alam Semesta dan sub tema Tata Surya yang bisa digunakan secara klasikal, kelompok maupun individu. Kemudian hasil uji coba lapangan awal dan uji coba lapangan produk utama melalui catatan lapangan menunjukan bahwa media ini sangat menarik antusias pada anak, dengan media Maket Tata surya ini memudahkan anak dalam mengenal nama- nama Planet dalam urutan Tata Surya, membuat anak berpatisipasi secara aktif dalam pembelajaran, memberikan ketertarikan dan menumbuhkan minat anak dalam belajar mengenal Tata Surya.

\section{Daftar Acuan}

Aprilia, P. W., \& Damayanti, M. I. (2019). Pengaruh penggunaan Media Maket Interior Ruang Kelas Terhadap Keterampilan Menulis Deskripsi Siswa Kelas II SDN Kedurus 1 Surabaya. JPGSD, 7, 2502-2514.

Aziz, R., \& Prasetya, S. P. (2018). Pengembangan Media Pembelajaran Maket 3D Geo grafi Pada Materi Lipatan dan Patahan Pengembangan Media Pembelajaran

Maket 3D Pada Materi Lipatan dan Patahan. Swara Bhumi, 5(9).

Hilmi, I., Nurhidayati, M., Nurlatifah, D., Febrian, R., \& Fanhas, E. (2017). Maket Kebun Binatang Berbasis Limbah Industri Rumahan sebagai Media Pembelajaran untuk Anak Usia Dini (AUD). Early Childhood: Jurnal Pendidikan, 1(1), 58-69. https://doi.org/10.35568/earlychildhood.v1i1.62

Kolta, E. N., Sholeh, A., \& Wijayanti, R. (2019). Pengembangan Media Shapes untuk Kreativitas Anak Usia Dini Kelompok B. Jurnal Inspirasi Pendidikan, 
9(1), 45-51.Retrieved from

http://ejournal.unikama.ac.id/index.php/jrnspirasi/article/view/3011

Kurniasih, R. (2014). Media Ular Tangga Jejak Petualang Sebagai Media. Cakrawala Dini, 5, 119-125.

Novitasari, E., Sumarni, S., \& Rahelly, Y. (2018). Pengembangan Media Maket Berbasis Kota Palembang Untuk Anak. Cakrawala Dini: Jurnal Pendidikan Anak UsiaDini, 9(2), 75-87.

Nurhafizah. (2018). Pelatihan Pembuatan Media Pembelajaran Anak Usia Dini Menggunakan Bahan Sisa. Early Childhood: Jurnal Pendidikan, 2(2b), 44-53. https://doi.org/10.35568/earlychildhood.v2i2b.288

Pratiwi, I. A. (2015). Pengembangan Model Kolaborasi Jigsaw Role Playing Sebagai Upaya Peningkatan Kemampuan Bekerjasama Siswa Kelas V Sd Pada Pelajaran Ips. Jurnal Konseling Gusjigang, 1(2). https://doi.org/10.24176/jkg.v1i2.411

Romelah. (2017). Model Simulasi Media Maket Dalam PembelajaranMembaca Denah Siswa SMPN 1 Punggelan, Banjarnegara. Cendekia, 11. https://doi.org/10.1017/CBO9781107415324.004

Sari, H. N., \& Daryono. (2019). Pengembangan Media Pembelajaran Maket Pada Materi Vulkanisme dalam Mata Kuliah Geologi Umum Prodi S1 Pendidikan Geografi Universitas Negeri Surabaya. Journal of Chemical Information and Modeling, 53 (9), 1689-1699. https://doi.org/10.1017/CBO9781107415324.004

Setiawan, A. (2018). Meningkatkan Kemampuan Berhitung Anak Usia Dini Melalui Media Pembelajaran Matematika di RA Ma'arif 1 Kota Metro. Seling:Jurnal Program Studi PGRA, 4, 181-188.

Zaini, B., \& Saputri, M. P. (2017). Pengembangan Media Pembelajaran Interaktif Contextual Teaching and Learning (CTL) Untuk Siswa Pendidikan Anak Usia Dini (PAUD) di PAUD Sahabat. Jurnal Pendidikan Teknik Informatika Dan Komputer, 1(2), 90-100.

Fajar, G. S., Prasetyo, R., Mahendra, D., Yamono. S.,(2019).Mokelis For Kids Modul Edukasi Listrik Sebagai Media Pembelajaran Keselamatan Listrik Anak Usia Dini.Jurnal Edukasi Elektro, Vol. 3, No. 1.

Nurhafizah,. (2018). Pelatihan Pembuatan Media Pembelajaran Anak Usia Dini Menggunakan Bahan Sisa. Jurnal Pendidikan: Early Childhood, Vol. 2No. 2

Hamzah, A. (2019). Metode Penelitian \& Pengembangan. Malang: CV. Literasi Nusantara Abadi. 